\title{
フレームに組み込まれたアンボンドブレースの弾塑性挙動解析
}

\section{ANALYTICAL STUDY ON UNBONDED BRACES FIXED IN A FLAME}

\author{
佐伯 英一郎*, 前田 泰史 ${ }^{* *}$, 岩松 浩 一***, 和田 章**** \\ Eiichiro SAEKI, Yasushi MAEDA, Kouichi IWAMATSU \\ and Akira WADA
}

Numerical analyses on buckling-restrained unbonded braces fixed in a frame were made using the non-linear finite element method and the following conclusions were obtained.

1) The hysterisis charachteristics and strain distributions of core steels on "frame model" are almost same as those on "basic model (non-eccentricity and no-moment model)."

2) The hysterisis charachteristics on "obliquely loaded model" are almost same as those of "basic model" although the strain distributions of core steels on "obliquely loaded model" are slightly larger at the end parts than those on "basic model."

3) Locally concentrated cumulative plastic strains of core steels due to earthquake are much small in comparison with cumulative plastic strain of steel to low cycle fatigue failure.

4) The hysterisis characteristics and strain distribution of extremely long unbonded braces are almost same as those of "basic model."

Keywords : unbond, brace, finite element method, hysterisis charachteristics, low cycle fatigue

アンボンド, ブレース, 有限要素法, 復元力特性, 低サイクル疲労

\section{1.まえがき}

「ブレース」は建築構造物の耐震要素として効果的であ り，低層から高層建築物まで幅広く使用されている。し かしながらブレースは圧縮力が作用すると座屈現象を起 こし耐力低下を生じる欠点がある。「アンボンドブレー ス」はこの年を解決するブレースとして考案され ${ }^{6)}$, 現 在多くの建築物に使用されている。

近年，アンボンドブレースの利用のされ方は単に耐震 要素という受動的な使用方法のみではなく，積極的に振 動性状をコントロールするためのツールとして使用され ている。従って, 従来以上の精緻な弾塑性挙動の分析と 安全性の確認が必要となり，特に芯材の塑性ひずみの分 布及び累積量の研究が必要となってきた。

このような背景の中で，大型実大のアンボンドブレー スの加力実験を実施し, 復元力特性に関する小型モデル との相違点の有無及びブレースに作用するモーメントの 影響について分析を試みた8)。さらに，この実大実験結果
と有限要素法による解析結果の比較検討を行うことによ

ク，アンボンドブレースの実挙動が再現できる解析モデ ルを提案し，弾塑性挙動を分析した9?。

本研究は,この解析モデルを使用して, 実際に建物に装 着されたアンボンドブレースの数值解析を行うことによ り, 実挙動の分析と安全性の確認を行うことを目的とする。

\section{2.アンボンドブレースの概要と本研究の目的}

\section{1 アンボンドブレースの概要}

アンボンドブレースとは，図2-1に示すように，軸方向 力を伝達する鋼板（以下，芯材と称す）を鋼管とモル夕 ルによって拘束することによって座屈を起こさないよう にしたブレースであり,詳細は文献 $6 ， 8$ を参照されたい。

本研究で対象とするアンボンドブレースには，芯材が 平板断面，十字断面の 2 種類があり，それぞれータイ プ,+タイプと称すことにする。
* 新日本製鐵株式会社建築事業部 室長 · 工修

**新日本製鐵株式会社建築事業部 工修

*** 日鐵プラント設計株式会社 C. A.グループ

**** 東京工業大学 教授·工博
Nippon Steel Corporation, M. Eng.

Nippon Steel Corporation, M. Eng.

Nittetsu Plant Designing Corporation

Prof., Tokyo Institute of Technology, Dr. Eng. 

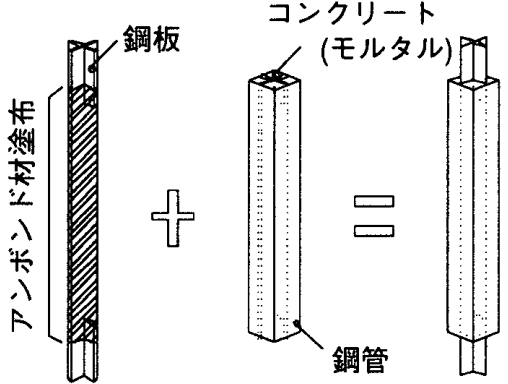

アンボンドブレース

図2-1 アンボンドブレースの構成

\section{2 本研究の目的}

筆者らは，文献 9 に示すよjなアンボンドブレースの 有限要素モデルを提案し，解析結果と実大実験結果を比 較検討することにより，数值解析モデルの妥当性を検証 した。本研究では，この数值解析モデルを用いて，アン ボンドブレースが柱, 梁フレームに組み込まれた「フレー ムモデル」及び端部の回転を拘束して斜め方向に加力す る「斜め加力モデル」の挙動を解析することにより，(1) フレームに組み込まれたアンボンドブレースのブレース 角度，長さ等が履歴特性に及ぼす影響，(2)ひずみ分布に 及ぼす端部拘束の影響と累積塑性ひずみ量の関係，(3)累 積塑性Uずみ量と低サイクル疲労強度の関係を明らかに することを目的とする。併せて，実プロジェクトの長尺 アンボンドブレースの数值解析を行うことにより, 弾塑 性挙動解析の分析と安全性を検討する。

\section{3. 解析方法}

\section{1 解析プログラム}

解析には有限要素法による沉用非線形構造解析プログ ラムを使用し，その詳細は文献 9 にゆずる。

\section{2 構成材料のモデル化（文献 9 参照）}

\section{2 .1 芯材及び鋼管}

芯材うよび鋼管は図3-1に示すように，処女載荷時に発 生する降伏棚及びバウシンガー効果を無視したバイリ二 ア型応力ーUずみ関係を有するものと仮定し，混合硬化 則を用いてモデル化する。混合硬化則の移動勾配は, 正負 对称に増加する繰り返し荷重下において一定の応力 $\left(\sigma_{1}\right)$ で降伏するように与えた。表3-1に解析用物性值を示す。 3.2 .2 モルタル

モルタルは図3-2に示す材料特性を有するものと仮定 する。材料は引張応力がクラック発生応力 $\left(\sigma_{1}=0.1 F_{C}\right)$ に達するとクラックが発生しその後一定の勾配 $\left(E_{s}\right)$ で 応力がゼロになるまで軟化する。压縮側では応力が降伏 応力 $\left(\sigma_{2}=1 / 3 F_{C}\right)$ に達すると降伏する。降伏後は一定の 公配 $\left(E_{2}\right)$ で応力は増加し塑性Uずみが圧壊ひずみ $\varepsilon_{\text {crush }}$
に達する（応力は $F_{C}$ に達する）と圧壊し，剛性はゼ口と なる。表3-2に解析用物性値を示す。

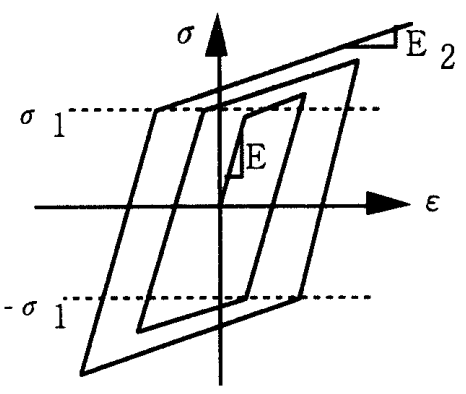

図3-1 鋼枋の応力ーUずみ関係

表3-1 鋼材の物性值

\begin{tabular}{|c|c|}
\hline ヤング率 $(\mathrm{E})$ & $21000 \mathrm{~kg} / \mathrm{mm}^{2}$ \\
\hline 降伏応力 $(\sigma 1)$ & $25 \mathrm{~kg} / \mathrm{mm}^{2}$ \\
\hline 第二勾配 $\left(\mathrm{E}_{2}\right)$ & $0.02 \mathrm{E}$ \\
\hline 加工硬化係数 & $428 \mathrm{~kg} / \mathrm{mm}^{2}$ \\
\hline 移動勾配 & $350 \mathrm{~kg} / \mathrm{mm}^{2}$ \\
\hline ポアソン比 & 0.3 \\
\hline
\end{tabular}

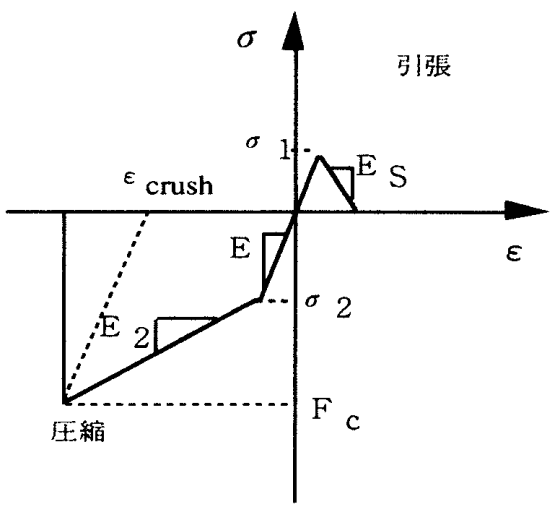

図3-2 モルタルの応力ーUずみ関係

表3-2 モルタルの物性值

\begin{tabular}{|c|c|}
\hline $\mathrm{Fc}$ & $3 \mathrm{~kg} / \mathrm{mm}^{2}$ \\
\hline クラック発生応力 $\left(\sigma_{1}\right)$ & $0.3 \mathrm{~kg} / \mathrm{mm}^{2}$ \\
\hline 降伏応力 $\left(\sigma_{2}\right)$ & $1 \mathrm{~kg} / \mathrm{mm}^{2}$ \\
\hline ヤング率 $(\mathrm{E})$ & $1500 \mathrm{~kg} / \mathrm{mm}^{2}$ \\
\hline 第二勾配 $\left(\mathrm{E}_{2}\right)$ & $706 \mathrm{~kg} / \mathrm{mm}^{2}$ \\
\hline ソフトニング係数 $\left(\mathrm{E}_{\mathrm{s}}\right)$ & $5000 \mathrm{~kg} / \mathrm{mm}^{2}$ \\
\hline 加工硬化係数 & $1333.3 \mathrm{~kg} / \mathrm{mm}^{2}$ \\
\hline 压壞ひずみ $\left(\varepsilon_{\text {cush }}\right)$ & $0.15 \%$ \\
\hline ポアソン比 & 0.15 \\
\hline せん断力保持率 & 0.05 \\
\hline
\end{tabular}




\section{4. 解析の種類と解析モデル}

文献 9 に示す「基本モデル（無偏芯単純交番載荷モデ ル)」を参考にして，以下に示す「フレームモデル」と「斜 め加力モデル」の解析を行う。

\section{1 フレームモデル}

4.1.1 解析モデル

フレームに組み込まれたブレースの挙動を把握するた め図4-1に示すフレームモデルを考える。解析を行うブ レースは, 表4-1に示すよjに400-36,400+28とそれぞ れのブレース材長を約 2 分の 1 とした400-36L2，400+ $28 \mathrm{~L} 2$ 㧍よび $400+28$ の鋼管板厚を $1.6 \mathrm{~mm}$ とした $400+28$ T16の 5 種類とする。材長 $1 / 2$ モデルは梁サイズ, ブレー又角度等の制約から短くせざるを得ない「短尺アンボン ドブレース」の挙動分析を目的とし，薄闪鍴管モデルは 鋼管の座屈拘束効果の影響の分析を目的とする。

4.1 .2 フレームのモデル化

フレーム (柱, 梁) は弾性体とし梁要素でモデル化す る。継手部も梁要素でモデル化し，岡性を柱の100倍とす ることにより，剛域として扱う。図4-2にフレームのモデ ル図（メッシュ分割図）を示す。

4.1 .3 ブレースのモデル化

図4-3にブレースのメッシュ分割図を示す。芯材はシェ ル要素, 鋼管及びモルタルはソリッド要素でモデル化し ている。モデルは対称性を利用して材軸方向に 2 分割し た1/2モデルとした。

\subsection{4 夕イイング及び境界条件}

境界条件を図4-4に示す。フレームの下部両端はヒンジ 支点とし、フレームの上部一端に載荷のための強制変位 を与える。ブレースとフレームは, 継手部先端で梁要素 とシェル要素をタイイングすることにより接続する。モ デル全体は $y-z$ 面対称であり, 芯材とモルタルは文献 9 と同様に材軸と直角な方向 $\left(z_{L}\right)$ の変位をタイイングす ることにより，アンボンド効果をモデル化している。材 軸方向 $\left(y_{L}\right)$ の変位はアンボンドブレースの中央で芯材 とモルタルをタイイングしている。

\section{1 .5 載荷方法}

図4-5に示す載荷パターンに従ってフレームに水平変 形を与える。（）内は増分ステップ数を示す。なお，基 本モデルと比較するために，ブレースの軸方向変形量が 一致するようなフレームの変形量を与えている。

表4-1 解析ケース (フレームモデル)

\begin{tabular}{|c|c|c|}
\hline 解析ケース & $\mathrm{L}(\mathrm{mm})$ & 備考 \\
\hline $400-36$ & 4340 & - \\
\hline $400+28$ & 4140 & - \\
\hline $400+28 \mathrm{~T} 16$ & 4140 & 薄肉鋼管モデル \\
\hline $400-36 \mathrm{~L} 2$ & 2100 & 材長 $1 / 2$ モデル \\
\hline $400+28 \mathrm{~L} 2$ & 2021 & 材長 $1 / 2$ モデル \\
\hline
\end{tabular}

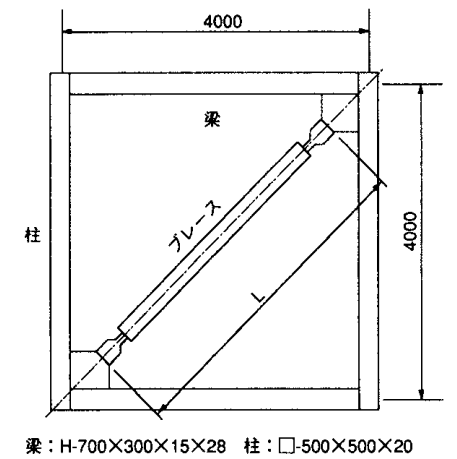

図4-1 解析モデル（フレームモデル）

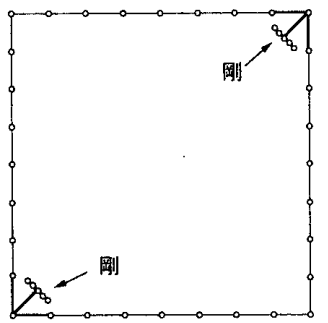

図4-2 フレームのモデル化

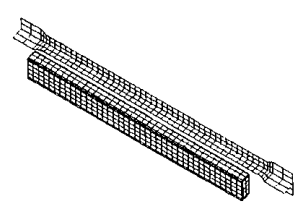

(+タイプ)

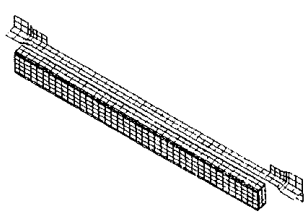

$(-タ イ フ ゚)$
図4-3 ブレースのメッシュ分割図

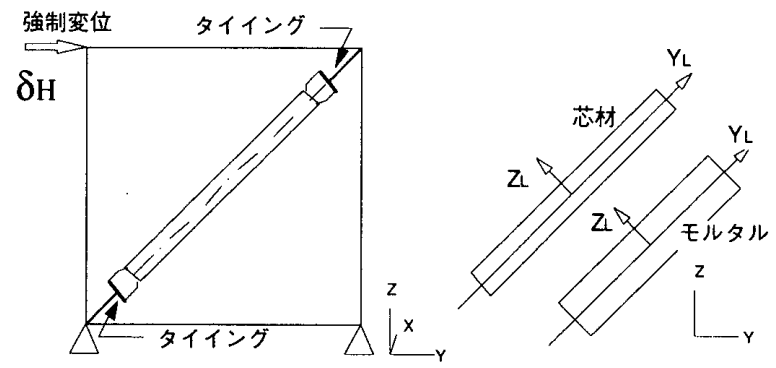

図4-4 境界条件

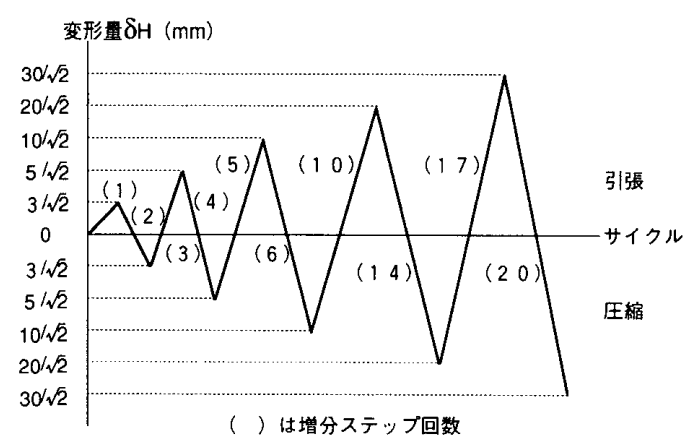

図4-5 載荷パターン 


\section{2 斜め加力モデル}

\section{2 .1 解析モデル}

フレーム内に装着されたブレ一スには，軸方向変形と 図4-6に示すモーメントを発生させる端部回転が生じる。 図4-7に示す斜め加力モデルはブレースが梁に取りつい ていると仮定した場合に梁の剛性が無限大の場合のブ レースの変形に対応し，フレームモデルよりも過大な モーメントをブレース端部に与える。

モーメントの対称性を利用して, 図4-6に示すブレース

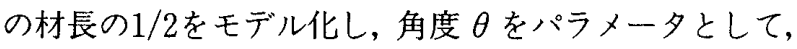
表4-2に示すような 6 種類の解析を行う。

\section{2 .2 載荷方法}

図4-8に示す載荷パターンに従ってブレース端部に材 軸と $\theta$ の角度に変形を与える。なお，基本モデルと比較 するために，ブレースの軸方向変形が一致するような変 形を与えている。

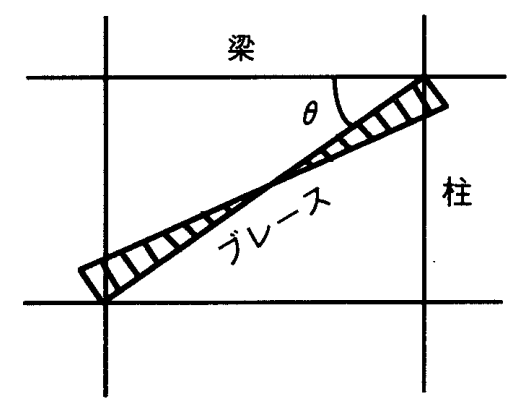

図4-6 ブレースに発生するモーメント

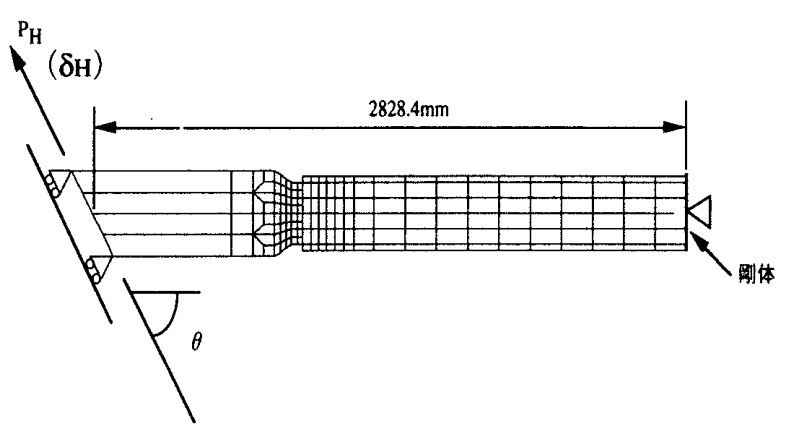

図4-7 解析モデル（斜め加力モデル）

表4-2 解析ケース (斜め加力モデル)

\begin{tabular}{|c|c|c|}
\hline 解析ケース & $\theta$ & タイプ \\
\hline $400-36 \theta 30$ & 30 & - \\
\hline $400-36 \theta 45$ & 45 & - \\
\hline $400-36 \theta 60$ & 60 & - \\
\hline $400+28 \theta 30$ & 30 & + \\
\hline $400+28 \theta 45$ & 45 & + \\
\hline $400+28 \theta 60$ & 60 & + \\
\hline
\end{tabular}

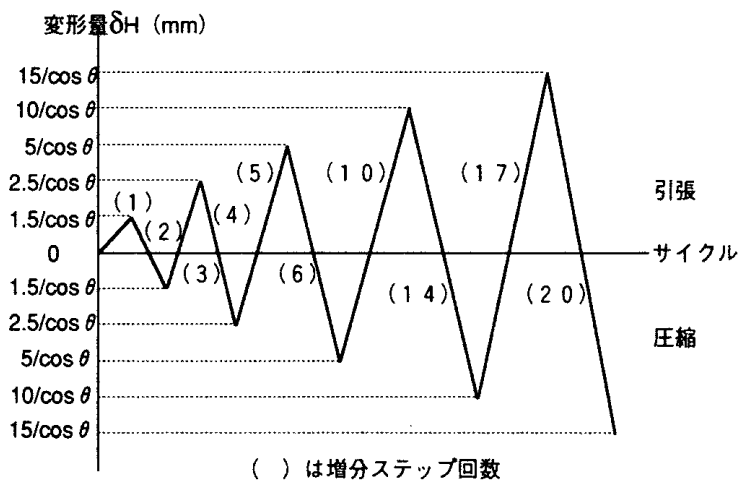

図4-8 載荷パターン

\section{5. 解析結果 (フレームモデ)}

解析結果と考察を以下に示す。なお，荷重の十側は引 張加力, 一側は圧縮加力を示す。

\section{1 復元力特性}

\section{(フレーム)}

$400-36,400+28,400-36 \mathrm{~L} 2,400+28 \mathrm{~L} 2$ 及び $400+28$ T16について, フレームの水平荷重 $\left(P_{H}\right)$ と水平変形 $\left(\delta_{H}\right)$ の関係を図5-1(a)〜(e)に示す。

いずれのケースにおいても座屈現象は生じておらず， 安定した復元力特性を示している。

(ブレース)

$400-36,400+28,400-36 \mathrm{~L} 2,400+28 \mathrm{~L} 2$ 及び $400+28$ T16について，ブレースにかかる軸方向荷重 $\left(P_{A}\right)$ と軸 方向変形 $\left(\delta_{A}\right)$ の関係を図5-2(a) (e)に示す。なお， $P_{A}$ は ブレースを含めたフレームのP $P-\delta$ 関係からフレームの みの $P-\delta$ 関係を差し引いて求めた。 $\delta_{A}$ は芯材両端中心 の 2 点の変位から求めた変形量とした。

フレームの場合と同様に, 安定した復元力を有し, 短 柱の圧縮引張試験と同様の復元力特性をもっていること がわかる。

\section{2 芯材の軸方向ひずみ}

(中央部, 端部)

$400-36,400+28,400-36 \mathrm{~L} 2,400+28 \mathrm{~L} 2$ 及び $400+28$ T16について, 図5-5に示す $B$ 点(中央部), $C_{1}, C_{2}$ 点(鋼 管内の芯材端部)における荷重 $\left(P_{A}\right)$ と軸方向Uずみ $\left(\varepsilon_{A}\right)$ の関係をそれぞれ図5-3(a)〜(e)，図5-4(a)〜(e)にそれぞれ 示寸。

図5-3，図5-4をみると,ータイプにおいて，(1)端部のリ ププレートの影響により $C_{1}, C_{2}$ 点のUずみが中央部 $(B$ 点）と比較してやや小さい值になっていること，(2)曲げ モーメントの影響により $C_{1}, C_{2}$ 点のUずみに差がある ことがわかる。しかし，いずれのケースにおいても引張 側，圧縮側のどちらかにひずみが累積している傾向はな く，原点を基準に正負バランス良く塑性Uずみが発生し ている。 

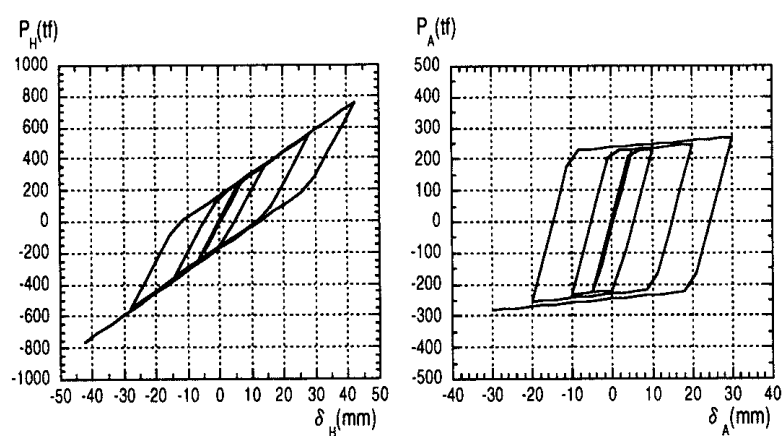

(a) $400-36$
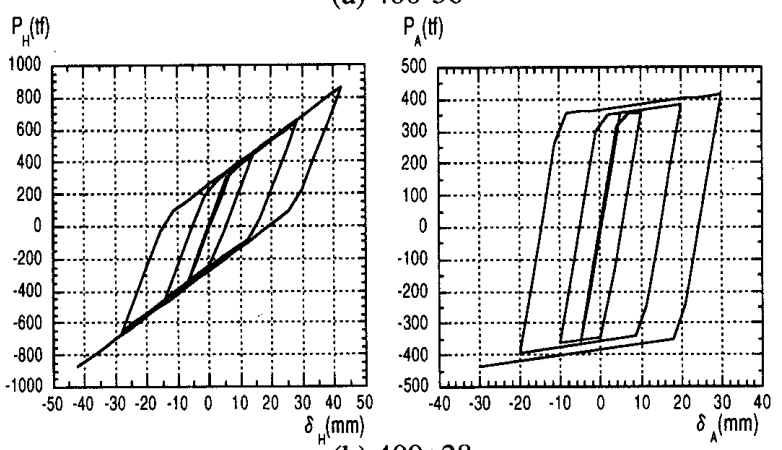

(b) $400+28$

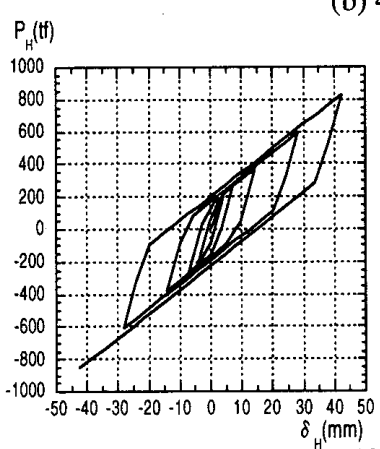

$P_{A}(t)$

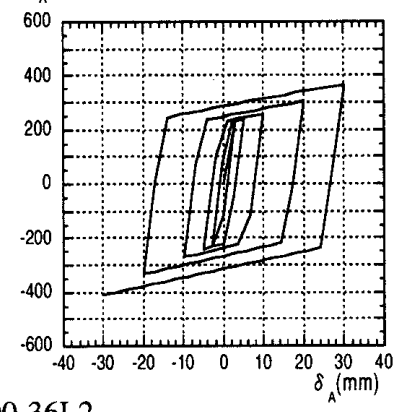

(c) 400-36L2
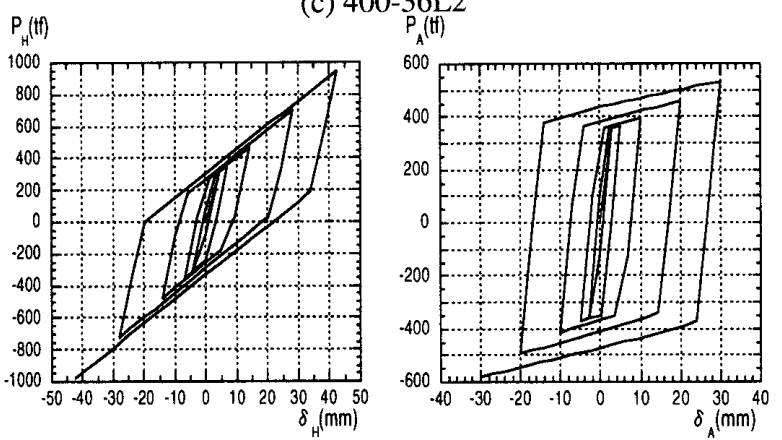

(d) $400+28 \mathrm{~L} 2$
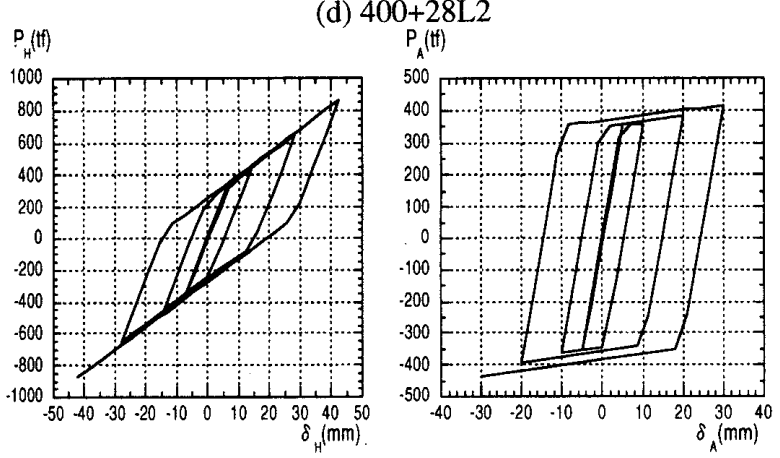

(e) $400+28 \mathrm{~T} 16$

左列：図5-1 水平荷重 $\left(P_{H}\right)$-一水平変形 $\left(\delta_{H}\right)$ 関係

右列：図5-2 荷重 $\left(P_{A}\right)$ 一軸方向変形 $\left(\delta_{A}\right)$ 関係
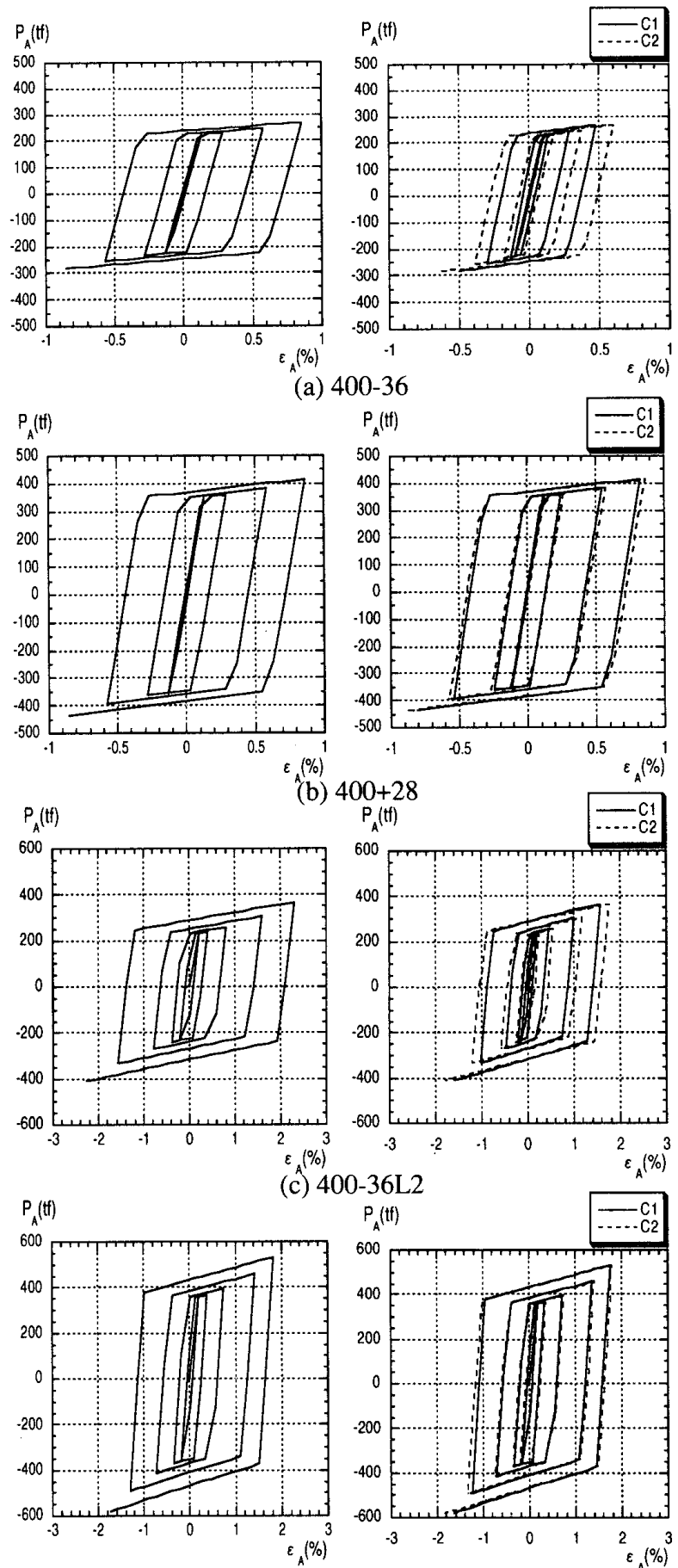

(c) $400-36 \mathrm{~L} 2$
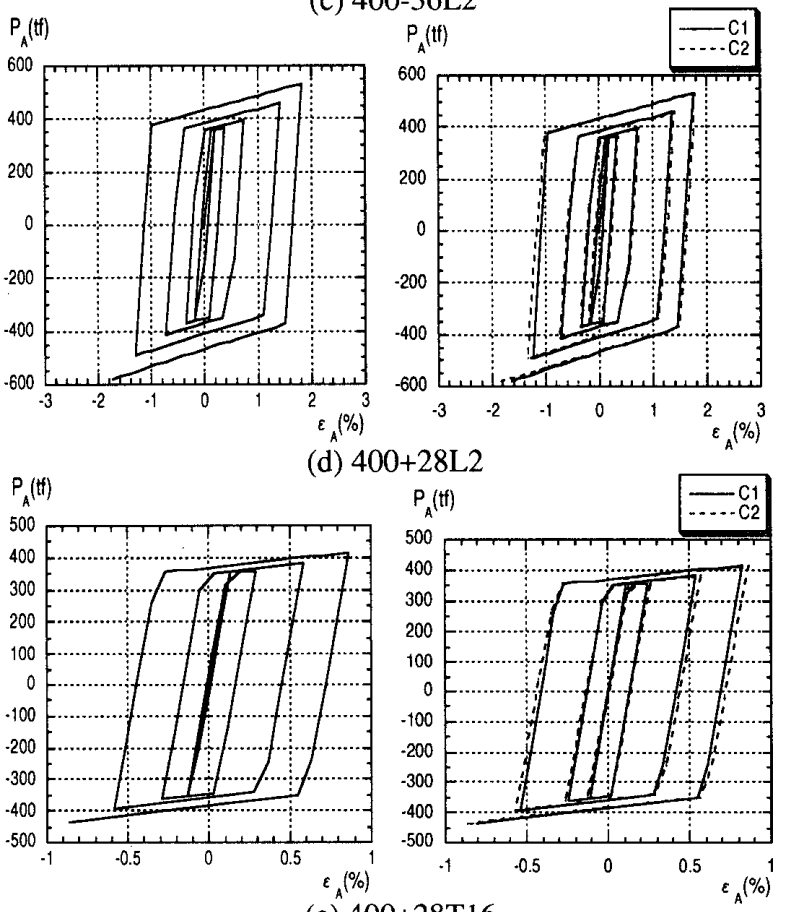

(e) $400+28 \mathrm{~T} 16$

左列：図5-3 荷重 $\left(P_{A}\right)$ 一軸方向Uずみ $\left(\varepsilon_{A}\right)$ 関係 (中央部) 右列：図5-4 荷重 $\left(P_{A}\right)$ 一軸方向Uずみ $\left(\varepsilon_{A}\right)$ 関係(端部) 
（軸方向Uずみ分布）

$400-36,400+28,400-36 \mathrm{~L} 2,400+28 \mathrm{~L} 2$ 及び $400+28$ T16について, 変形 $\left(\delta_{A}\right)$ が士10,20，30のときの $A \sim A^{\prime}$ 線上（図5-5参照）における軸方向Uずみ $\left(\varepsilon_{A}\right)$ の值を図 5-6(a) 〜 (e)に示す。

ータイプ (400-36, 400-36L2) において, $A, A^{\prime}$ 点 付近でひずみの值が小さくなっているのは，芯材中央部 と比較して端部の断面積が大きいためである。一方，十夕 イプにおいては，モーメントの影響により端部の塑性化 が進行しており，両端に大きな曲げUずみが発生してお ク，その傾向は短尺ブレースにおいてより顕著である。

\section{3 芯材の相当塑性ひずみ分布}

困5-7に $400-36,400+28 の \delta_{A}=-30 \mathrm{~mm}$ における芯 材の相当塑性Uずみ分布図を示す。

+タイプはータイプと比較して芯材端部のUずみ集中 が激しいことがわかる。

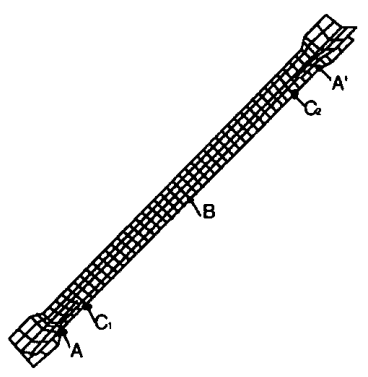

$($ ータイプ)

図5-5 Uずみ测定点(フレームモデル)

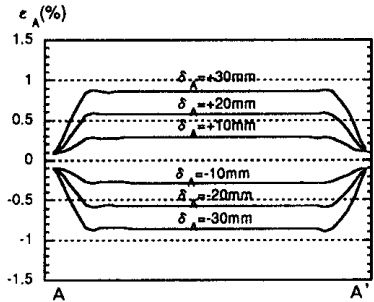

(a) $400-36$

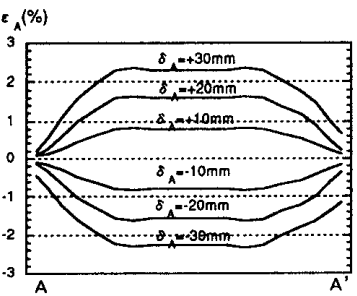

(c) $400-36 \mathrm{~L} 2$

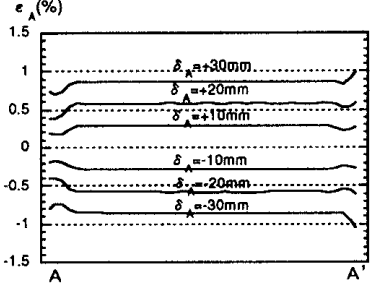

(e) $400+28 \mathrm{~T} 16$

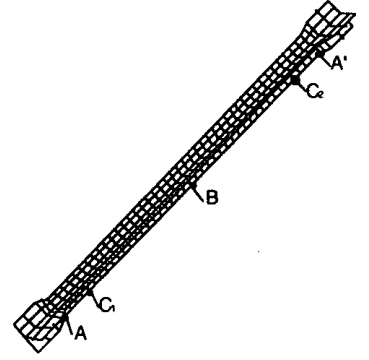

$(+タ イ フ ゚)$

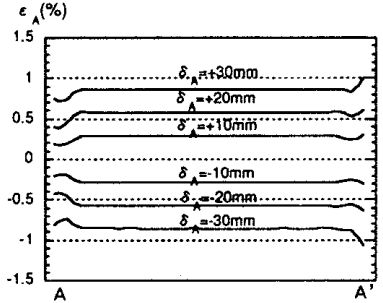

(b) $400+28$

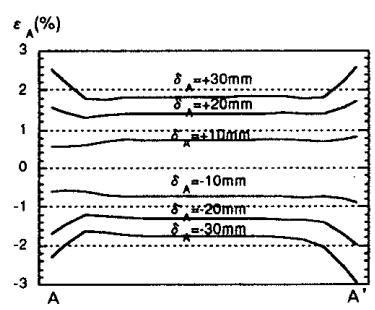

(d) $400+28 \mathrm{~L} 2$
図5-6 軸方向Uずみ分布 (フレームモデル)

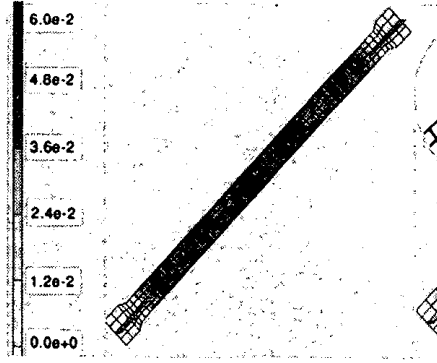

(a) $400-36$

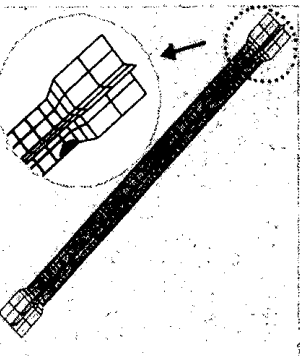

(b) $400+28$
図5-7 芯材の相当塑性ひずみ分布図 $(+30 \mathrm{~mm})$

\section{6. 解析結果 (斜め加力モデル)}

\section{1 復元力特性}

$400-36 \theta 30,400-36 \theta 45,400-36 \theta 60,400+28 \theta 30$, $400+28 \theta 45$ 及び $400+28 \theta 60$ について,ブレースにかかる 荷重 $\left(P_{A}\right)$ と軸方向変形 $\left(\delta_{A}\right)$ の関係を図6-1(a) ( $\left.\mathrm{f}\right)$ に示 す。

フレームモデルと同様に，いずれも安定した復元力を 有していることがわかる。また, 載荷角度による相違は ほとんどみられなく，通常，フレーム内において装着さ れるブレース角度の範囲においては，端部に作用する曲 げモーメントが復元力特性に与える影響はほとんどない といってよい。

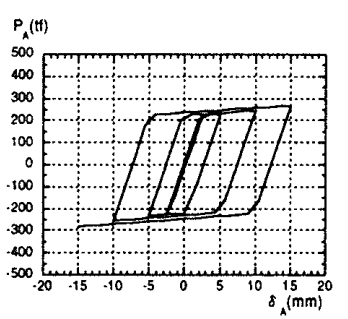

(a) $400-36$ o 30

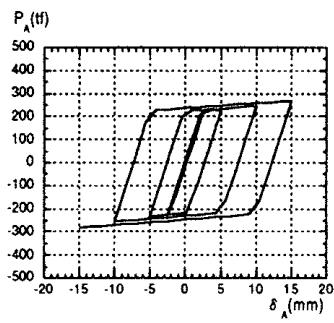

(b) $400-36 \theta 45$

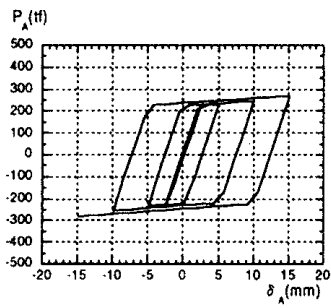

(c) $400-36 \theta 60$

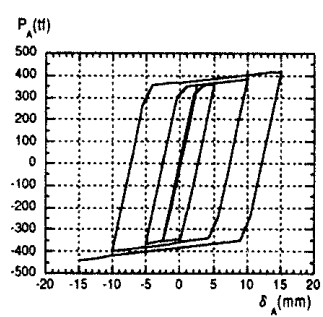

(d) $400+28 \theta 30$

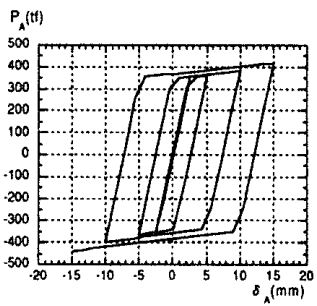

(e) $400+28 \theta 45$

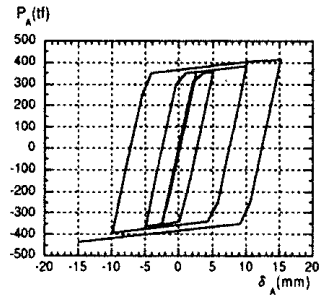

(f) $400+28 \theta 60$
図6-1 荷重 $\left(P_{A}\right)$ 一軸方向変形 $\left(\delta_{A}\right)$ 関係 

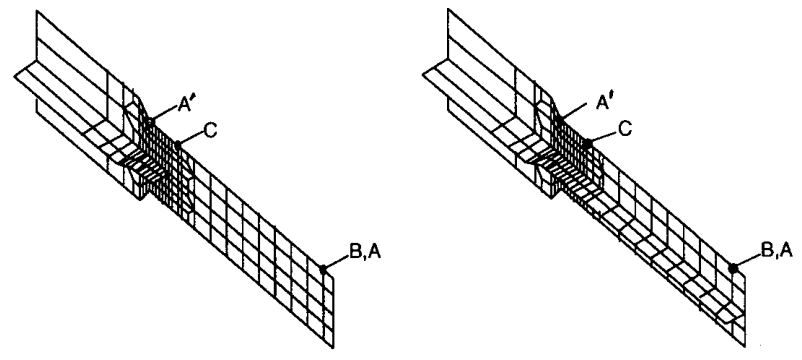

(ータイプ)

$(+タ イ フ ゚)$

図6-2 Uずみ測定点（斜め加力モデル）

\section{2 芯材の軸方向ひずみ}

(中央部，端部)

$400-36 \theta 30,400-36 \theta 45,400-36 \theta 60,400+28 \theta 30$, $400+28 \theta 45$ 及び $400+28 \theta 60$ につい, 図6-2に示す $B$ 点 (中央部), $C$ 点 (鋼管内の芯材端部) における荷重 $\left(P_{A}\right)$ と軸方向ひずみ $\left(\varepsilon_{A}\right)$ の関係を図6-3(a)〜 $(\mathrm{f})$, 図6-4(a)〜 $(\mathrm{f})$ に示す。

基本モデル，フレームモデルと異なり，強制変形によ る曲げモーメントの影響により，鋼管内の芯材端部のU ずみの值が中央部よりもやや大きくなっていることがわ かる。しかしながら，引張側，圧縮側のどちらかにUず みが集中的に累積することはなく，点対称型のカーブを 描いている。

（軸方向ひずみ分布）

$400-36 \theta 30,400-36 \theta 45,400-36 \theta 60,400+28 \theta 30$, $400+28 \theta 45$ 及び $400+28 \theta 60$ について, 変形 $\left(\delta_{A}\right)$ が士 5 , 10，15mmのときの $A \sim A^{\prime}$ 線上（図6-2参照）における 軸方向Uずみ $\left(\varepsilon_{A}\right)$ の值を図6-5(a)〜(f)に示す。

一タイプの場合は端部のリブプレートの取りつく断面 の付近, +タイプの場合は $A^{\prime}$ 点の付近で急激にUずみ の值が大きくなっている。この傾向は, $\theta$ の值が大きいほ ど, 即ち, ブレースが立っているほど顕著になっている。 特に, 十タイプは座屈拘束モルタルの外部の芯材に塑性 Uずみの集中が激しい。これは，ブレースの回転角が大 きく，その回転を拘束している端部に大きな曲げひずみ が発生するためである。

\section{3 芯材の相当塑性ひずみ}

図6-6に $400-36 \theta 45,400+28 \theta 45$ の $\delta_{A}=-15 \mathrm{~mm}$ にお ける芯材の相当塑性Uずみ分布図を示す。

フレームモデルと同様に十タイプは一タイプと比較し て，芯材端部への塑性ひずみの集中が激しくその傾向は より顕著である。

\section{7. 材端条件の違いと復元力特性}

「フレームモデル」，「斜加力モデル」の解析結果を文
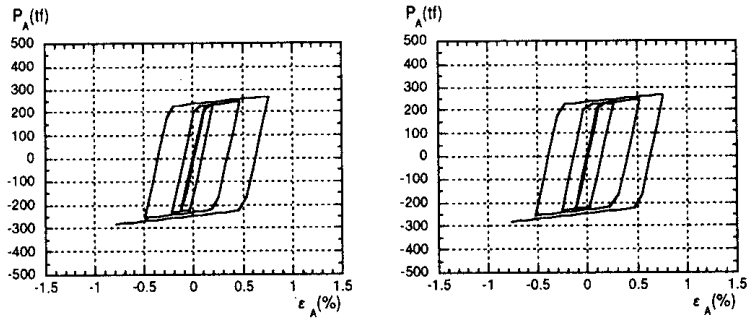

(a) $400-36 \theta 30$
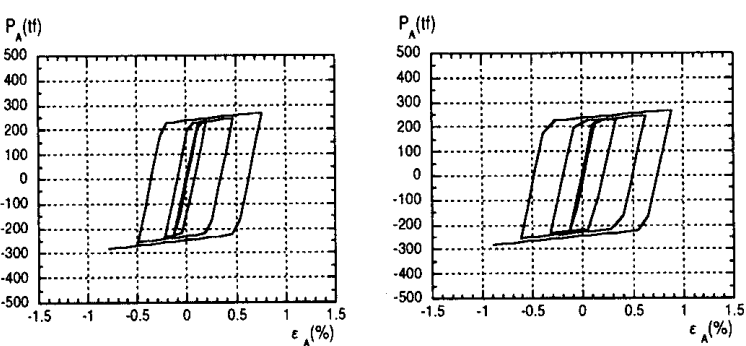

(b) $400-36 \theta 45$
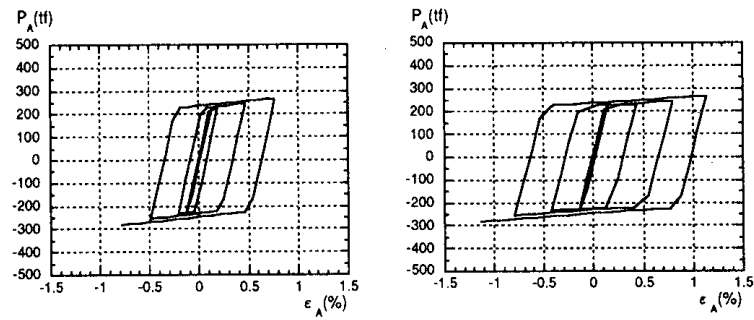

(c) $400-36 \theta 60$
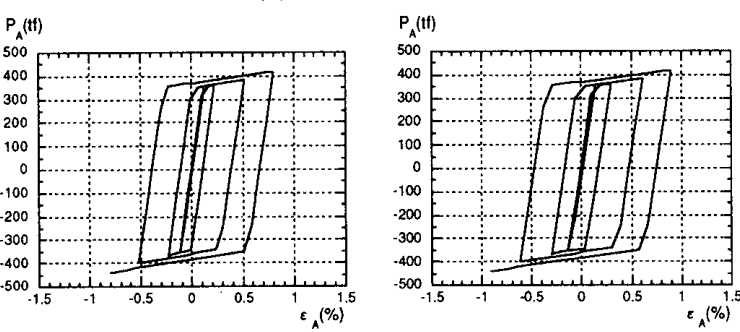

(d) $400+28 \theta 30$
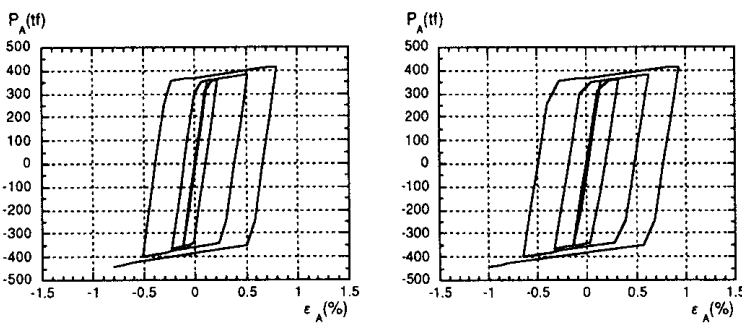

(e) $400+28 \theta 45$
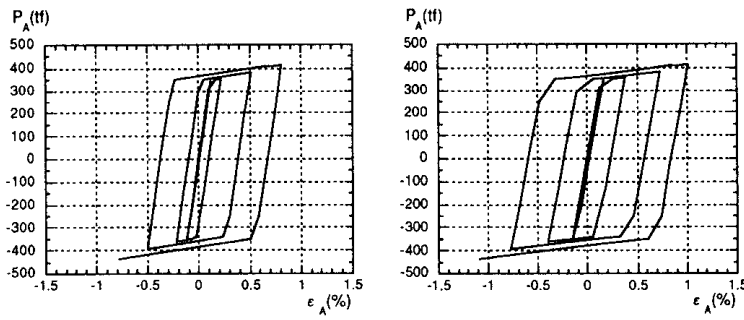

(f) $400+28 \theta 60$

左列：図6-3 荷重 $\left(P_{A}\right)$ 一軸方向Uずみ $\left(\varepsilon_{A}\right)$ 関係（中央部） 右列：図6-4 荷重 $\left(P_{A}\right)$ 一軸方向Uずみ $\left(\varepsilon_{A}\right)$ 関係（端部) 


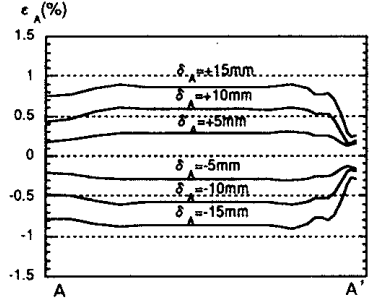

(a) $400-36 \theta 30$

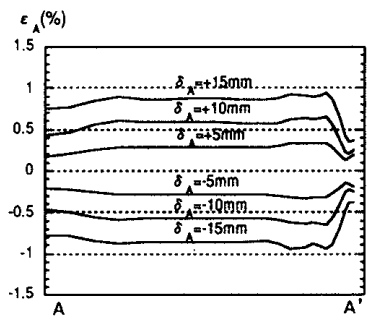

(b) $400-36 \theta 45$

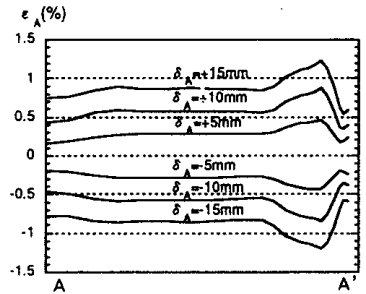

(c) $400-36 \theta 60$

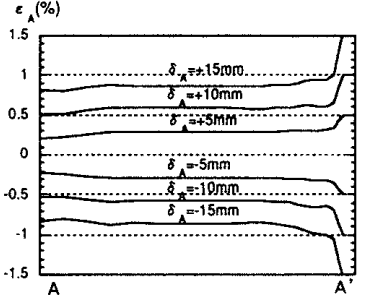

(d) $400+28 \theta 30$

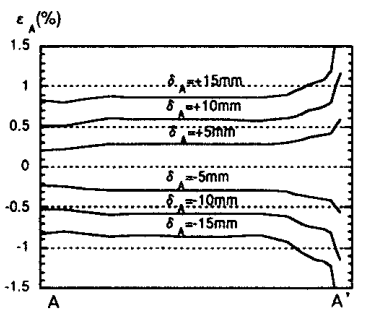

(e) $400+28 \theta 45$

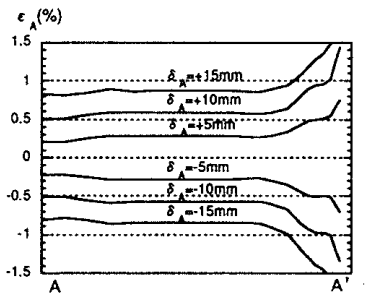

(f) $400+28 \theta 60$
图6-5 軸方向ひずみ分布（斜め加力モデル）

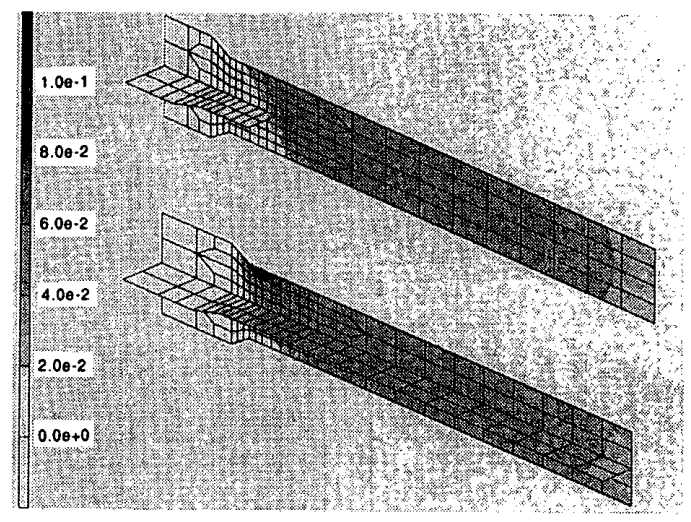

図6-6 芯材の相当塑性ひずみ分布図 $(+15 \mathrm{~mm})$ (上段： $400-36 \theta 45$ 下段： $400+28 \theta 45$ )

献 9 に示す「基本モデル」の解析結果と比較することに より，材端条件の及ぼす復元力特性への影響を考之る。 なお，斜め加力モデルについては，フレームモデルと対 応させるため, $\theta=45^{\circ}$ の結果を用いる。また, 基本モデル, 斜め加力モデルは材長を半分にした $1 / 2$ モデルであるた め, 軸方向変形の值を 2 倍している。

\section{1 復元力特性}

一タイプ,+タイプにおいて, 各モデルのブレースにか かる荷重 $\left(P_{A}\right)$ と軸方向変形 $\left(\delta_{A}\right)$ の関係を図7-1(a)，(b) に示す。なお，基本モデル，フレームモデルについては,

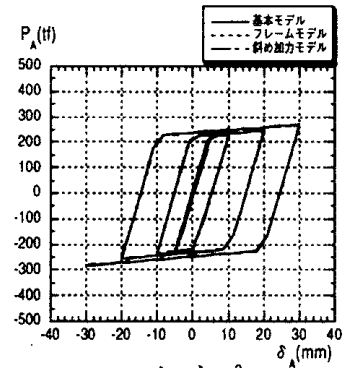

(a) - タイプ

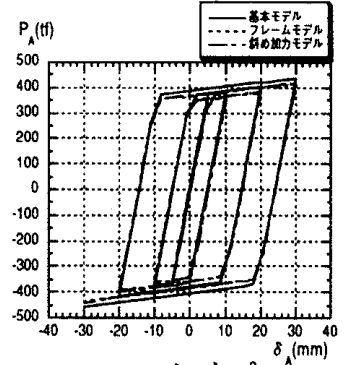

(b) + タイプ 図7-1＼cjkstart各モデルの復元力特性

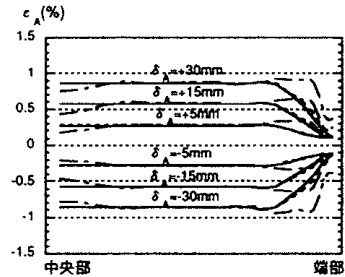

(a) - タイプ

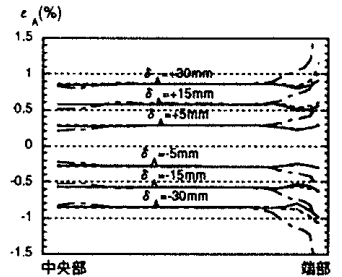

(b) + タイプ

図7-2 各モデルの軸方向Uずみ分布 (凡例は図7-1を参照)

400-36, $400+28$ 解析結果であり, 斜め加力モデルに ついては，400-36 $\theta 45 ， 400+28 \theta 45$ の解析結果である。

この罒からわかるように, 一タイプについては復元力 の差異は全くないが,十タイプについては端部の塑性化 の違いによりやや各モデルの復元力に差異が発生してい ることがわかる。

\section{2 軸方向ひずみ分布}

一タイプ, +タイプについて, 軸方向変形 $\left(\delta_{A}\right)$ が \pm 10 , 20, 30mmのときの芯材中央部から鋼管内の端部にかけ ての軸方向ひずみ $\left(\varepsilon_{A}\right)$ の值を図7-2(a)，(b)に示す。

+タイプ,ータイプ共に, 基本モデルとフレームモデル の軸方向Uずみ分布にはほとんど差がないことがわか る。一方，斜め加力モデルは端部拘束による過大な付加 曲げモ一メントが生じるため，他のモデルと比較して端 部のUずみの值が大きい。しかし，7.1で述べたように履 歴特性に及ぼす影響は非常に小さい。

\section{8. 果積塑性ひずみと低サイクル疲労強度 \\ 8.1 地震時に発生する累積塑性ひずみ}

フレームに装着されたブレースの最大変形 $( \pm 30 \mathrm{~mm})$ は, ほほ層間変形 $1 / 100 に$ 対応し，その際のブレース端部 の最大軸方向Uずみは，400+28L2において 2 2\%で ある。斜め加力モデルの結果より，400+28 $\theta 30$ の端部軸 方向ひずみは， $400+28 \theta 45$ の端部軸方向ひずみより約 15\%大きく，ブレース角度によりさらに大きな軸方向ひ ずみが発生することが推定できる。 
一方，原田，秋山は地震による累積塑性変形倍率は最 大塑性変形倍率の 4 〜 倍程度であると報告してい る7。従って,アンボンドブレ一ス端部に発生する最大塑 性ひずみ $\left(\varepsilon_{p}\right)$ 及び累積塑性ひずみ $\left(\sum \varepsilon_{p}\right)$ の範囲は, 図8-1に示す範囲を想定しておけば十分に安全サイドで ある。

\section{2 低サイクル疲労強度と安全性の検討}

鋼の低サイクル疲労特性については多くの研究があ

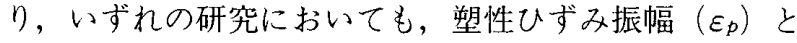
破壊に至る繰り返し回数 $\left(N_{f}\right)$ の間に次のような関係を 導いている。

$$
\varepsilon_{p}=C_{1} N_{f}^{m l}
$$

$$
\begin{array}{lll}
\text { Manson }^{1 /} は & C_{1}=\varepsilon_{f}^{0.6} & m_{1}=-0.6 \\
\text { Martin' }^{2)} は & C_{1}=1 / \sqrt{2} \varepsilon_{f}^{0.6} & m_{1}=-0.5 \\
\text { Coffin }^{3)} & C_{1}=2 \varepsilon_{f} & m_{1}=-0.5
\end{array}
$$

を提案しており，いずれの提案式も静破壊延性 $\left(\varepsilon_{f}\right)$ の 関数として与えられている。 $40 \mathrm{~kg}$ 鋼〜 $60 \mathrm{~kg}$ 鋼では， $\varepsilon_{f}$ の值は鋼種によって明瞭な傾向はなく，成分等のばらつ きによって0.8〜1.4の值となる。

破断に至るまでの累積塑性Uずみ $\left(\sum \varepsilon_{p}\right)$ は

$$
\sum \varepsilon_{p}=2 \varepsilon_{p} N_{f}=2 C_{1} N_{f}^{(1+m l)}
$$

で表わすことができる。

図8-1は Manson と Martinの提案式を用いて， $\varepsilon_{f}=$ $0.8,1.4 の$ 場合の $\sum \varepsilon_{p}$ と $\varepsilon_{p}$ の関係を示している。これを みると，鋼の破壊に至るまでの累積塑性ひずみ量は，地 震によるアンボンドブレース端部の累積塑性ひずみ量と 比較して一般的には充分に大きく安全であることがわか る。しかしながら，鋼材にノッチ等が存在した場合の低 サイクル疲労強度については充分なデータが無く、フ レース端部のUずみ集中は極力少なくなるように努力す ることが望ましい。

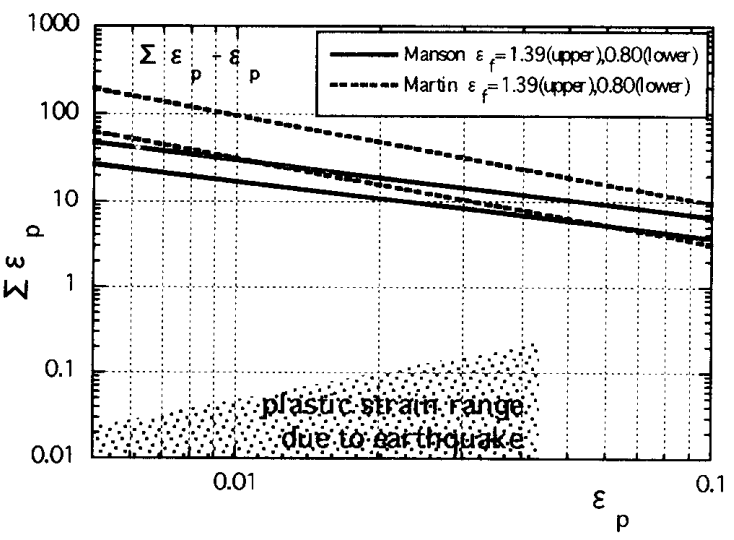

図8-1＼cjkstart糸積塑性ひずみ $\left(\Sigma \varepsilon_{p}\right)$ と塑性ひずみ振幅 $\left(\varepsilon_{p}\right)$ の関係

\section{9. 長尺アンボンドブレースの解析}

大スパン重層建築物の最も好ましい構造形式としてメ ガストラクチャーが挙げられる。その耐震要素として長 尺のアンボンドブレースを採用することが検討され，そ の一例として材長約 $20 \mathrm{~m}$ のアンボンドブレースの数值 解析結果の概要を紹介する。

\section{1 解析モデルと解析方法}

解析ケースの概要を表9-1に, 解析モデル及び境界条件 を図9-1に示す。解析方法については，3.に示した方法 と同様である。載荷パターンを図9-2に示寸。なお，水平 変位 $300 \mathrm{~mm}$ は層間変形角にして約 $1 / 50$ に相当する。ま た，自重による曲げモーメントの影響を安全側に評価す るため，実際の自重の2 倍の值を与える。

表9-1 解析ケースの概要

\begin{tabular}{|c|c|c|}
\hline フレーム & $\mathrm{B}(\mathrm{mm})$ & 22500 \\
\cline { 2 - 3 } & $\mathrm{H}(\mathrm{mm})$ & 11000 \\
\hline \multirow{2}{*}{ 芯材 } & タイプ & + \\
\cline { 2 - 3 } & 断㨁 $(\mathrm{mm})$ & $40 \times 550$ \\
\cline { 2 - 3 } & 材質 & $\mathrm{SM} 520$ \\
\cline { 2 - 3 } & $\mathrm{L}(\mathrm{mm})$ & 21234 \\
\hline 鋼管 & 断喕 $(\mathrm{mm})$ & $\square-750 \times 750 \times 28$ \\
\cline { 2 - 3 } & 材質 & $\mathrm{SS} 400$ \\
\hline
\end{tabular}

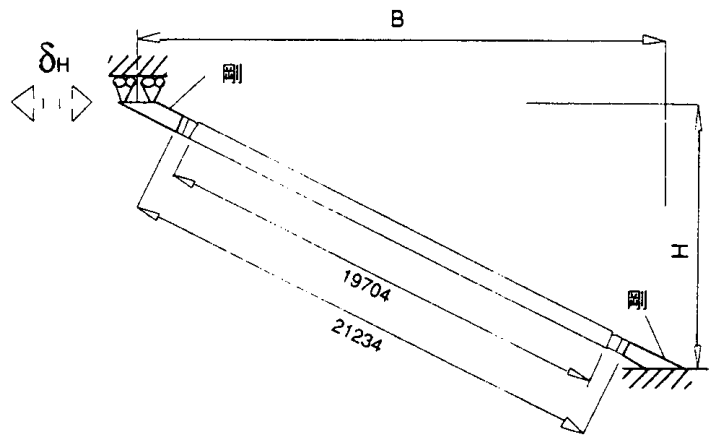

図9-1 解析モデル及び境界条件

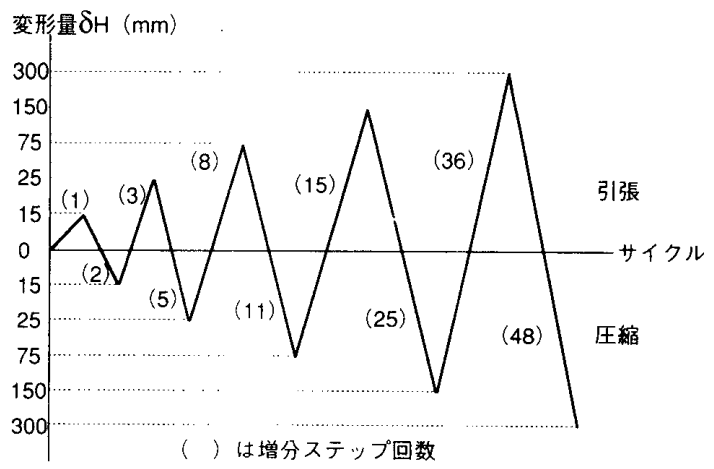

図9-2 載荷パターン 

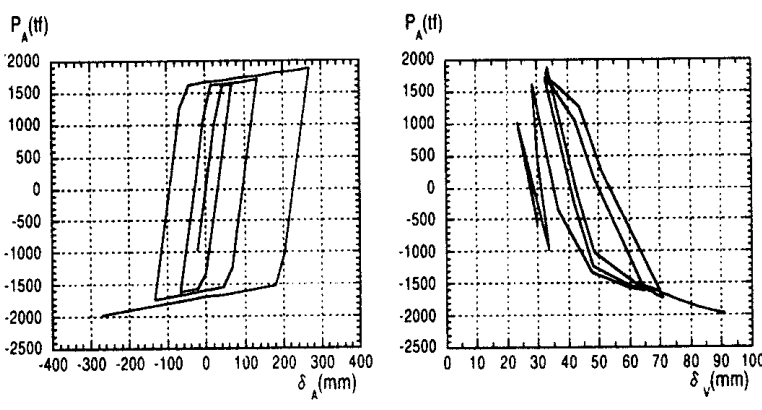

左：図9-3 荷重 $\left(P_{A}\right)$ と軸方向変形 $\left(\delta_{A}\right)$ の関係

右：図9-4 荷重 $\left(P_{A}\right)$ と軸外方向変形 $\left(\delta_{V}\right)$ の関係

\section{2 解析結果}

\section{(復元力特性)}

ブレースにかかる荷重 $\left(P_{A}\right)$ と軸方向変形 $\left(\delta_{A}\right)$, 軸外 方向変形 $\left(\delta_{V}\right)$, の関係を図9-3, 図9-4にそれぞれ示す。 なお，軸外方向変形とは，ブレース中央部における，材 軸と直角方向の変形である。

四9-3をみると, 自重を本来の 2 倍与えるという厳しい 条件下においても，座屈現象は生じておらず安定した復 元力を有している。約 $20 \mathrm{~m}$ の長尺の鋼管コンクリートに おいても，鋼管に発生している応力には余裕があり，座 屈拘束効果は充分であることがわかる。図9-4より，軸外 方向の変形は, 自重のみの場合で約 $30 \mathrm{~mm}$, また, 層間変 形角 $1 / 100$ の場合で約 $70 \mathrm{~mm}$ であり，材長の約 $1 / 300 の$ 変 形に相当する。

\section{0. 結論}

本研究より得られた結論を以下に示す。

1) フレームに装着されたアンボンドブレースの挙動に ついて数值解析を行った結果, 復元力特性及びブレ一 ス芯材のUずみ分布は「基本モデル（無偏心単純交番 載荷モデル)」とほとんど差異はない。
2 ）端部回転を拘束した斜め加力モデルは, ブレース端 部のUずみがやや大きくなるが，復元力特性は「基本 モデル」とほぼ等しく，端部に発生する曲げモーメン トが復元力特性に与える影響は少ない。

3）地震によるアンボンドブレース端部の累積塑性Uず み量は，鋼の破壊に至るまでの累積塑性ひずみ量と比 較して充分に小さい。

4) 約 $20 \mathrm{~m}$ の長尺アンボンドブレースについても, 座屈 現象は生じず安定した復元力特性を有する。

\section{参考文献リスト}

1) S.S. Manson: Thermal Stress and Low Cycle Fatigue, McGrawHill, 1966

2) D.E. Martin: An Energy Criterion for Low Cycle Fatigue, Trans. ASME (Series D), April (1921), pp.565. 571

3) L.F. Coffin, Jr. : Experimental Support for Generalized Equation Predicting Low Cycle Fatigue, Journal of Basic Engineering, Trans. ASME (Series D), December (1962), pp.533-537

4）佐伯，杉沢他：低降伏点鋼の低サイクル疲労特性に関する 研究，日本建築学会論文報告集，1995年 6 月，pp.139-148

5）佐伯，杉沢他：低降伏点鋼のヒステリシス及びヒステリシ スエネルギー特性に関する研究, 日本建築学会論文報告集, 1995年 7 月, pp. $159-168$

6）藤本，和田，佐伯他：鋼管コンクリートにより座屈を拘束 したアンボンドブレースに関する研究，構造工学論文集 Vol.34B，1988年 3 月, pp.249 257

7）原田，秋山：エネルギ集中型混合骨組の耐震設計，日本建 築学会論文報告集，第472号，1995年 6 月，pp.57-66

8）佐伯, 前田他：実大アンボンドブレースに関する実験的研 究, 日本建築学会諭文報告集, 第476号, 1995年10月, pp. $149-158$

9）佐伯, 前田他：有限要素法によるアンボンドブレースの弾 塑性解析と実験結果との比較, 日本建築学会論文報告集, 第484号，1996年 6 月（揭載予定）

（1996年 3 月 5 日原稿受理，1996年 6 月20日採用決定） 